\title{
NUMERICAL INVESTIGATION OF CHOCKED CONVERGING-DIVERGING NOZZLES FOR THRUSTER APPLICATION
}

\author{
M.H.M. NOH, A.H.A. HAMID, R. ATAN AND H. RASHID \\ Faculty of Mechanical Enineering, University Technology MARA (UiTM), \\ 45400 Shah Alam,Selangor, Malaysia. \\ mhafiz_noh@yahoo.com
}

\begin{abstract}
The need for low-thrust propulsion systems for small scale spacecraft is growing. Low thrust characteristics generally lead to low Reynolds number flows from propulsive devices that utilize converging-diverging nozzle. In the present work, seven choked converging-diverging nozzle flow characteristics operating at Reynolds number of 46000 are numerically investigated using a commercial software FLUENT 6.1.22. Computational work is carried out using axisymmetric flow Spalart-Allmaras model, twodimensional, axisymmetric, coupled solver and linearized using implicit scheme. The nozzles, which are intended to be used for thruster application, have a throat diameter of 11 $\mathrm{mm}$ and an area ratio of 4 . All six nozzles are derived from a nozzle with divergence angle of $28^{\circ}$, where the divergence angle is reduced while maintaining the area ratio. The main objective of this work is to investigate the performance and flow characteristic of nozzles with different geometry. Numerical findings show that there is thrust reduction observed as the divergence angle reduces from $28^{\circ}$ to $10^{\circ}$, except for nozzle with divergence angles of $16^{\circ}$ and $18^{\circ}$, where they produce thrusts higher than their derivative one. Numerical result also reveals that the flow separation phenomenon occurs inside all nozzles, where normal shock forms inside nozzles with divergence angle of $20^{\circ}, 14^{\circ}$ and $10^{\circ}$, and this shock degrades the performance of the nozzle in term of the thrust produced.
\end{abstract}

ABSTRAK: Keperluan sistem kuasa kipas tujahan rendah bagi pesawat angkasa berskala kecil makin meningkat. Umumnya ciri-ciri tujahan rendah membawa kepada aliran nombor Reynolds yang rendah dari alat dorongan yang menggunakan muncung tumpu-capah. Buat masa ini, tujuh muncung cekik tumpu-capah beroperasi pada nombor Reynolds 46000 telah dikaji menggunakan perisian komersil FLUENT 6.1.22. Kerja pengiraan dijalankan dengan menggunakan model aliran simetri sepaksi Spalart-Allmaras, dua dimensi, simestri sepaksi, penyelesai terganding dan dilinearkan menggunakan skim tersirat. Muncung tersebut, yang tujuannya adalah untuk digunakan dalam aplikasi penujah, mempunyai lubang berdiameter $11 \mathrm{~mm}$ dan bernisbah luas 4 . Kesemua enam muncung diterbitkan daripada satu muncung dengan sudut capahan $28^{\circ}$, dimana sudut capahan telah dikurangkan sementara nisbah keluasan dikekalkan. Tujuan utama penyelidikan ini adalah untuk mengkaji prestasi dan ciri aliran muncung yang berbeza geometri. Hasil kajian menunjukkan bahawa kuasa tujahan menurun apabila sudut capahan dikurangan dari $28^{\circ}$ ke $10^{\circ}$, kecuali muncung bersudut capahan $16^{\circ}$ dan $18^{\circ}$, yang menghasilkan kuasa tujahan lebih tinggi berbanding muncungmuncung terbitan yang lain. Keputusan berangka juga menunjukkan bahawa fenomena pemisahan aliran berlaku di dalam kesemua muncung, dimana kejutan normal terjadi di dalam muncung dengan sudut capahan $20^{\circ}, 14^{\circ}$ dan $10^{\circ}$, dan kejutan ini mengurangkan prestasi muncung tersebut dari segi kuasa tujahan yang dihasilkan.

KEYWORDS: flow separation; normal shock wave; divergence angle; supersonic nozzle 


\section{INTRODUCTION}

Aerospace propulsion system is a system in which the fundamental principle obeys Newton's laws, namely that force is proportional to rate of change of momentum, and that action and reaction are equal and opposite [1]. Thrust chamber is one example of a system that works using these laws besides other systems i.e. turbojet and ramjet. Thrust chamber is a system that provides thrust by expelling stored matter, called the propellant. This thrust can range from mega-Newton to milli-Newton. Thrust chamber system can be main spacecraft propulsion i.e. rocket engine, auxiliary spacecraft propulsion, satellite launcher, missile launcher, assist-take-off engines for airplanes and even ejection of crew escape capsules. Small thrusters are usually used as secondary spacecraft propulsion system in which some of the functions are attitude control, spin control, stage separation and station keeping.

Liquid propellant thrust chamber generally consists of injector, combustion chamber and convergent-divergent (C-D) nozzle or DeLaval nozzle. Propellant is injected through an injector and burned in combustion chamber and produces hot gases. The gases move towards the nozzle throat at a subsonic flow. This process continues until there is enough pressure builds up to force a part of them out of a nozzle throat at supersonic velocity. A carefully designednozzle's divergence part is vital as it will determine the overall efficiency of the thruster. The movement of gases through the nozzle results in the conversion of heat energy into kinetic energy, or energy of motion. Figure 1 shows schematic diagram of typical liquid propellant thrust chamber with the three major zones within the combustion chamber. They are:

- Injection/atomization zone

- Rapid combustion zone

- Stream tube combustion zone

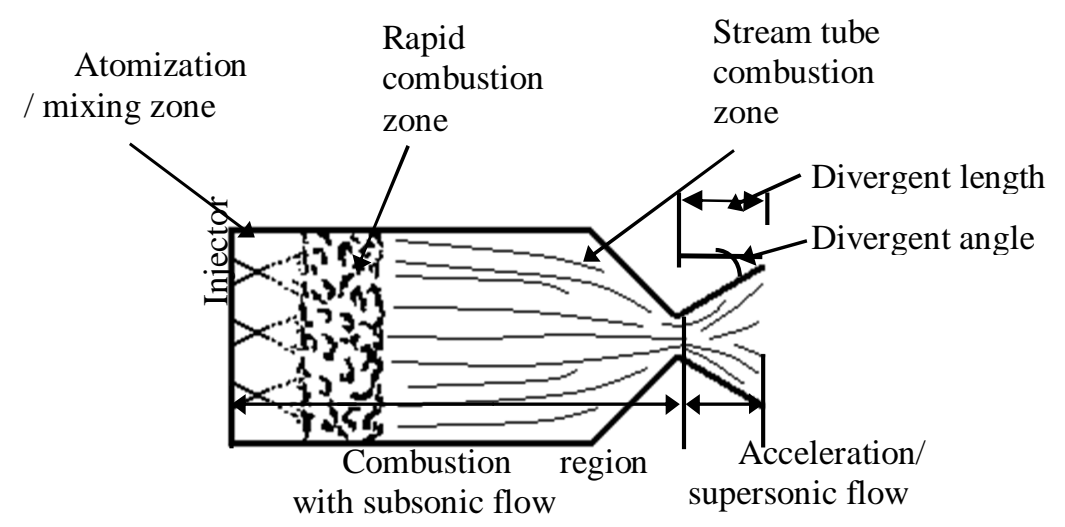

Fig. 1: Schematic diagram of typical liquid propellant thrust chamber.

The purpose of the thruster nozzle is to increase the acceleration of the gases as they leave the rocket and thereby maximizing the thrust.Nozzle is basically characterized by the configuration, i.e. geometrical shapes of nozzle's divergent portion (bell, conical or trumpet), the divergence angle and the area ratio (ratio of nozzle exit area to the throat area). Selection of "correct" nozzle configuration is very important as it will improve the overall performance 
of the thrust chamber.However, the best nozzle configuration depends on several factors and also fabrication capabilities and cost involved.

\section{NOZZLE CONFIGURATION AND ITS ASSOCIATION WITH OVERALL PERFORMANCE}

Pearson, Landrum and Hawk [2] have done numerical investigation on performance losses in small thrust chamber nozzles. They found that the viscous effect was the largest contributor to performance loss amongst two other losses mechanisms; chemical kinetics loss and divergence loss. This result further strengthens the research finding by Grisnik and Smith [3]. Numerical results also showed that the viscous loss mechanism is the most sensitive to the nozzle downstream geometry variations, i.e. the divergence angle which largely determines the rate of expansion of the flow. The effect of viscous is reduced when the divergence angle is low and the flow was allowed to expand more gradually. To understand this, one must realize that viscous loss is contributed by two factors: viscous drag on the nozzle walls and flow blockage due to boundary layer growth. In the latter case, the high divergence angle produces thicker viscous boundary layer and smaller inviscid core flow which will "block" the stream. In the former case, a low divergence angle will reduce the nozzle's wetted surface. They reported that a specific impulse gain of 130 seconds was predicted by a numerical code when the divergence angle was reduced from the baseline value of $45^{\circ}$ to $20^{\circ}$. Lowering the divergence angle also leads to another desirable effect: decrease in chemical kinetic loss [2].

It is also reported that this performance gain is offset slightly by the increase in divergence loss with decreasing divergence angle. It is because a large divergence angle allows the flow to expand quickly and hence more time for axial turning of the flow. The divergence losses are almost eliminated by increasing the diverging angle to $65^{\circ}$ [2]. Lengthening the nozzle is also an alternative, though this may increase the viscous loss since the nozzle's wetted surface increase and there is also an increase in nozzle weight to a point that it is not practical for mission considerations. More recent research by Ketsdever, Clabough, Gimelshein and Alexeenko [4] have proved that shortening the nozzle resulted in higher axial flow velocities at the nozzle exit plane caused by asmaller impact of the viscous layer. They also found contradicting results where the viscous effect wasminimum at the largest divergence angle. Numerical analysis showed that there was an increase in specific impulse when the divergence angle was doubled from $20^{\circ}$ to $40^{\circ}$. This numerical data had proved the previous experimental results obtained by Whalen [5], where it is found that $25^{\circ}$ conical nozzle had slightly better efficiency, at lower Reynolds number as compared to $20^{\circ}$ conical nozzle.

\section{FLOW SEPARATION PHENOMENON}

Flow separation inside supersonic nozzle is almost impossible to be avoided for a fixed nozzle configuration. Flow separates fully from the nozzle wall due to the presence of an oblique shock wave, which is also known as separation shock wave that originates from the nozzle wall and is directed towards the nozzle centerline. This separated shear layer flows as a free jet and it is termed as free shock separation (FSS) since no reattachment occurs downstream of separation location [6]. By definition, oblique shock wave is a shock wave 
which is inclined to the flow direction inside the nozzle and it is formed from the nozzle wall due to the induced adverse pressure gradient [7]. Reverse flow region exists at the downstream of the separation location in which the ambient air is being sucked into the nozzle due to the effect of the separated flow.

Another type of flow separation is restricted shock separation (RSS) where the separated flow is then reflected towards the wall by the radial momentum of the separated jet which is directed towards the wall, forming a cap-shock pattern [8]. During real operation, there will be transition from FSS structure to RSS structure when the pressure ratio increases, as discussed by Östlund [7] and Nebbache and Pilinski [9]. Separated flow inside the nozzle is undesirable as transition of flow separation structure from FSS to RSS will produce side load to nozzle wall which may present life-limiting constraints on both the nozzle itself and other engine components $[6,7,10$ and 11]. Furthermore, flow separation phenomena tend to reduce the nozzle efficiency, i.e. thrust produced [8].

In this study, seven different nozzles went through the performance testing and all nozzles were designed with the same configuration which is conical convergent-divergent and same throat diameter of $11 \mathrm{~mm}$. The varied parameters are divergence angle and divergence length.

\section{MATERIALS AND METHODS}

The computational work was carried out to investigate the performance of seven different nozzles in term of flow characteristics. Six nozzles are derived from a nozzle with divergence angle of $28^{\circ}$, where the divergence angle is reduced while maintaining the same area ratio. Table 1summarizes the nozzles dimensions. The detail of fluid property is summarized in Error! Reference source not found.

Table 1: Tested nozzles dimensions.

\begin{tabular}{ccc}
\hline Nozzle & Divergence angle $\left(^{\circ}\right)$ & $\begin{array}{c}\text { Divergence length } \\
(\mathrm{mm})\end{array}$ \\
\hline 1 & 28 & 22.1 \\
2 & 24 & 25.9 \\
3 & 20 & 31.2 \\
4 & 18 & 34.7 \\
5 & 16 & 39.1 \\
6 & 14 & 44.8 \\
7 & 10 & 62.9 \\
\hline
\end{tabular}

All nozzles were modeled and meshed using Gambit 2.1.6[14, 15], then, it is solved by Fluent software $[14,15]$. Fluent software was chosen to solve the flow problem since several researchers had used this CFD software and found that the theoretical data provided gives a good agreement with experimental data $[12,13]$. Since the nozzles have a circular crosssection, it is reasonable to assume that the flow is axisymmetric. So the nozzles geometry was created in two-dimensional. Fig.1 shows the typical geometry and grid distribution inside the 
nozzle. The grid density is higher in the divergent part of the nozzle and clustered at the nozzle exit to improve the resolution for capturing shocks.

Table 2: Fluid properties.

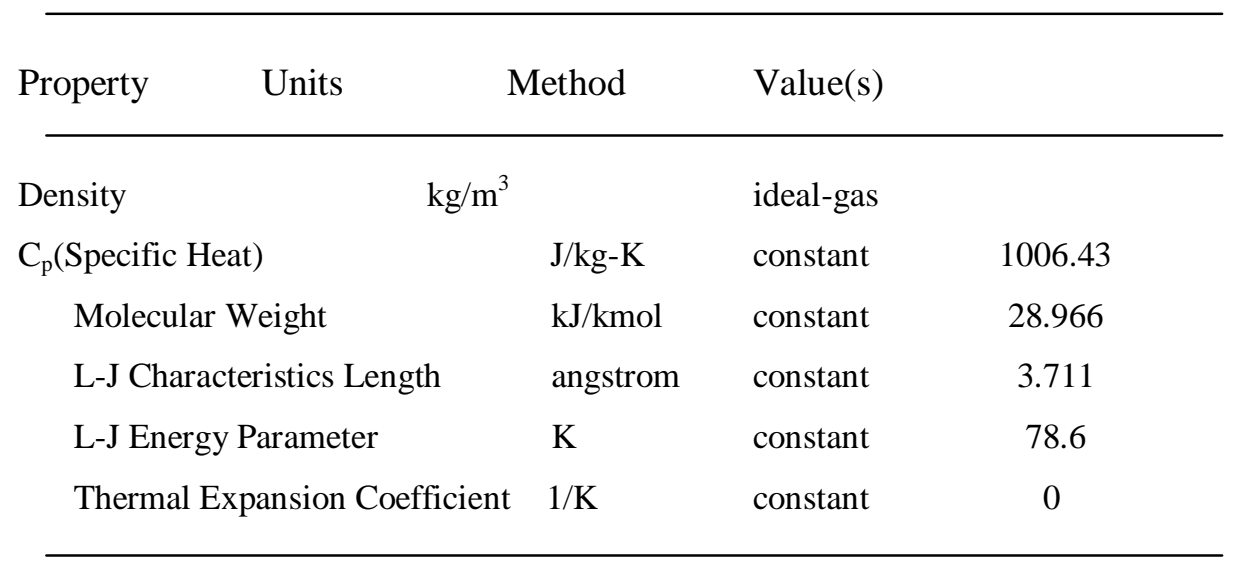

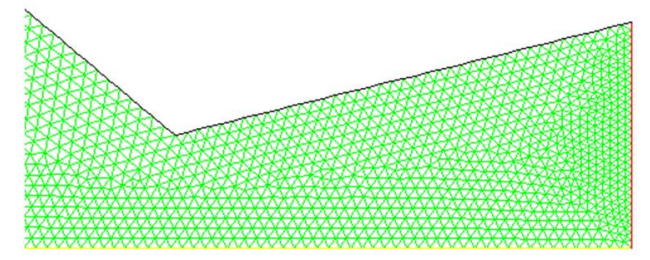

Fig.1:Grid distribution inside nozzle 1.

For solving the problem, computational work was carried out using a two-dimensional, axisymmetric, coupled solver (which solves the governing equations of continuity, momentum, and energy simultaneously) and linearized using a implicit scheme to predict the performance of the thrust chamber nozzles. Coupled solver was used since it is recommended when dealing with applications involving high speed compressible flows and the governing equations was linearized using implicit scheme since it will generally converge much faster than the explicit solver [14]. Spalart-Allmaras model was used as a turbulence model as it is designed specifically for aerospace applications involving wall-bounded flows and has been shown to give good results for boundary layers subjected to adverse pressure gradients [15]. Furthermore, Charmeau and Anghaie [16] cited that this one-equation model has shown good accuracy in the analyses of converging-diverging nozzles.

Boundary conditions are imposed as follows: pressure and temperature at the nozzle inlet are set to be $\mathrm{P}=500 \mathrm{kPa}$ and $\mathrm{T}=3400 \mathrm{~K}$ respectively to model the combustion pressure and temperature. The nozzle outlet pressure and temperature were set at $100 \mathrm{kPa}$ and $2490 \mathrm{~K}$ respectively. The simulation was initially conducted with the initial guess values to be the ones at the inlet. 


\section{RESULTS AND DISCUSSION}

Computed Mach number contours for these nozzles are shown in Fig. 2. The black circle on the figure indicates the position of the normal shock at the symmetry axis and the open circle indicates the position of the reflection of the internal shock at the symmetry axis.

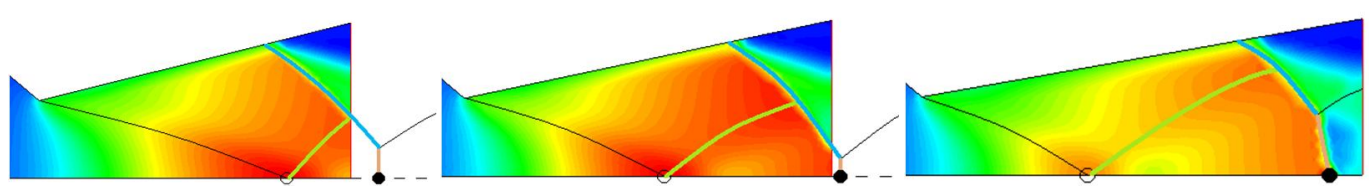

a)

b)

c)

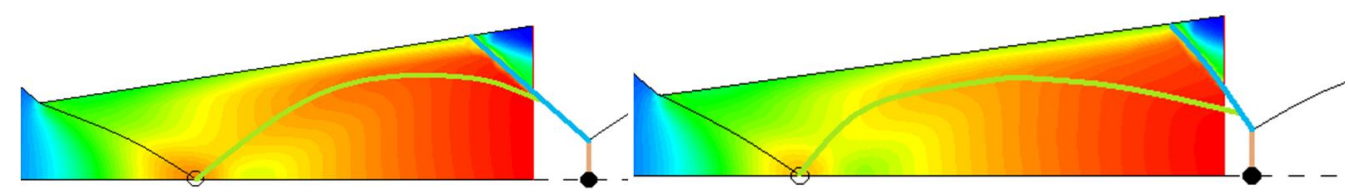

d)

e)

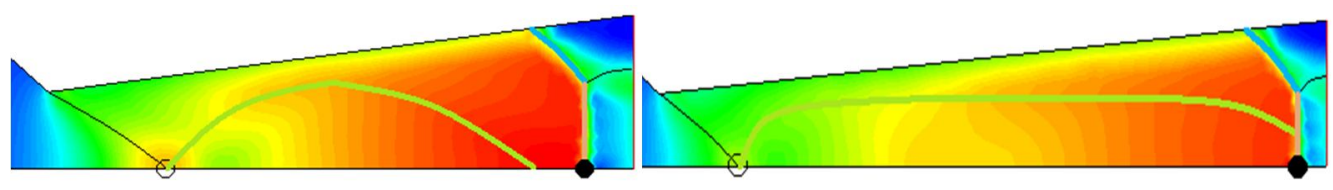

f)

g)

Position of the normal shock at the symmetry axis

Oosition of the reflection of the internal shock at the symmetry axis

Fig. 2 :Mach number contour, (a)nozzle 1, (b)nozzle 2, (c)nozzle 3, (d)nozzle 4, (e)nozzle 5 , (f)nozzle 6, and (g)nozzle 7.

It can be seen from Fig. 2a and $3 b$ that the normal shock wave (represented by the brown line) forms at the outside of the nozzle. A normal shock is a very thin region, perpendicular to the direction of a supersonic flow, through which the flow suddenly changes from supersonic to subsonic. This thin region is also known as Mach disc.

The position of the normal shock wave at the symmetry axis moves upstream as the divergence angle was reduced until it is located inside the nozzle, as shown in Fig. 2c. At this point, the normal shock wave forms at the inside of the nozzle. Further reduction in divergence angle was caused the reflected shock wave (represented by the green line) intersected with the separation shock wave (represented by the blue line) at the outside of the nozzle, and this was believed to be a reason why the normal shock wave is formed at the outside of the nozzle, as shown in Fig. $2 \mathrm{~d}$ and $3 \mathrm{e}$. At the same time, the position of the normal shock wave at the symmetry axis moves upstream until it is located at the inside of the nozzle again, causing the normal shock wave to form at the inside of the nozzle, as shown in Fig. 2f and $3 g$. 
Numerical result also reveals that the thrust produced by the nozzle depends on the flow characteristics inside it. Table 1 summarizes the expected thrust produced by all nozzles.

Table 1: Expected thrust for all nozzles.

\begin{tabular}{|c|c|c|c|}
\hline Nozzle & Thrust (N) & Nozzle Divergence Angle $\left({ }^{\mathrm{O}}\right)$ & $\begin{array}{c}\text { Thrust reduction (\%), } \\
\Delta \text { Thrust }\end{array}$ \\
\hline 1 & 45.08 & 28 & 0 \\
\hline 2 & 37.13 & 24 & 17.6 \\
\hline 3 & 31.69 & 20 & 29.7 \\
\hline 4 & 49.60 & 18 & -10 \\
\hline 5 & 50.81 & 16 & -12.7 \\
\hline 6 & 32.52 & 14 & 27.9 \\
\hline 7 & 31.01 & 10 & 31.2 \\
\hline
\end{tabular}

Based on this thrust data, it was observed that the nozzles where normal shock wave formed inside it had the lowest thrust produced, which is nozzle 3, nozzle 6 and nozzle 7 as compared to other nozzles. It is due to the fact that the flow at the exit plane of these nozzles is dominated by the subsonic core (Fig.4). This subsonic core has led to a low average gas velocity at the exit plane and hence the thrust produced.

The thrust data also shows that reducing the divergence angle from $28^{\circ}$ to $24^{\circ}$ while maintaining the area ratio reduces the thrust by $17.6 \%$. The thrust reduction is due to the increase in divergence loss with decreasing divergence angle. It is because a small divergence angle allows the flow to expand slowly and hence less time for axial turning of the flow. The thrust reduction is also due to the increment of nozzle's wetted surface as a result of lower divergence angle, which may results in higher viscous loss.

However, there is a contradicting result showed by nozzle 4 and nozzle 5. A slight increment in thrust, which is $2.4 \%$, was observed as the divergence angle reduced from $18^{\circ}$ to $16^{\circ}$. This contradiction can be explained as follows: the viscous loss is reduced when the divergence angle is low since low divergence angle produces thinner viscous boundary layer and larger inviscid core flow which will increase the velocity of the outgoing stream. Furthermore, lowering the divergence angle also tend to reduce the chemical kinetic loss [2].

It is also important to mention that nozzle 4 and nozzle 5 produce thrusts higher than their derivative one. Referring to Fig. 3, the location of flow separation at the nozzle wall move downstream as the divergence angle is reduced to $18^{\circ}$ and the point of separation moves upstream further as the divergence angle is reduced to $16^{\circ}$. As a result, the volume of the reverse flow region decreases and the supersonic flow cross sectional area at the exit plane 
becomes larger. This explains why nozzle 4 and nozzle 5 produce thrusts higher than their derivative one. Furthermore, the location of normal shock wave depends on local pressure. The adverse pressure gradient creates the normal shock wave and the separation points plays an important role in determining the location of the normal shock wave.

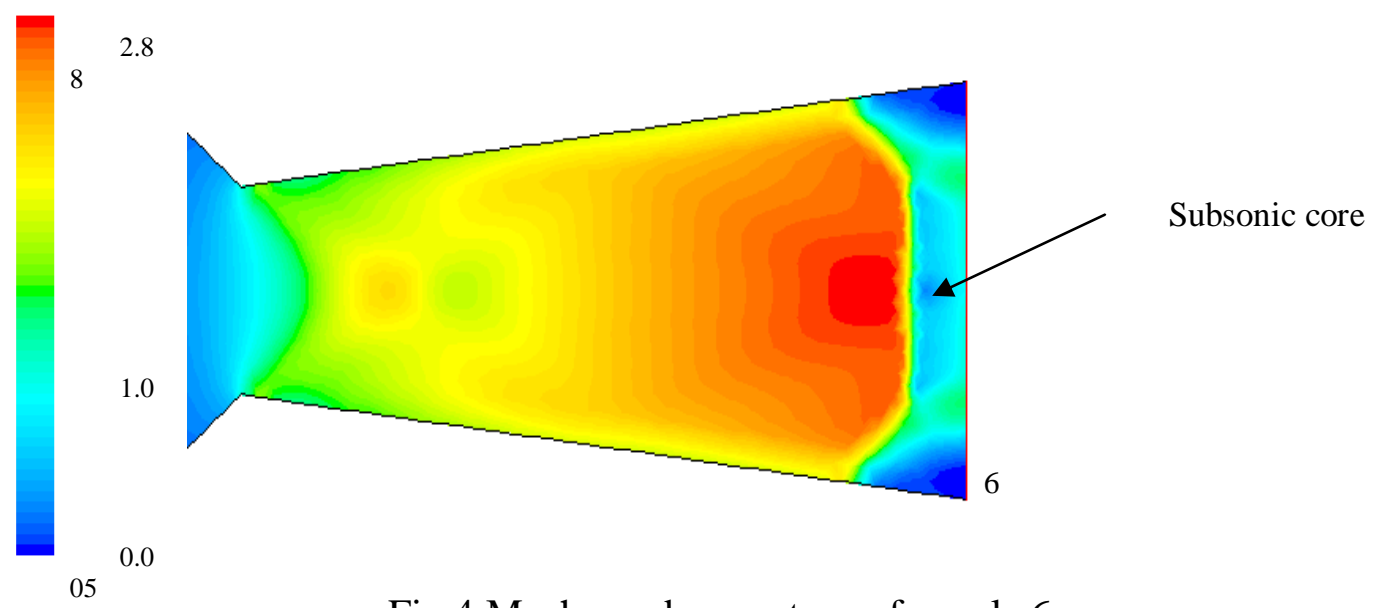

Fig.4:Mach number contour of nozzle 6.

\section{CONCLUSIONS}

A total of seven nozzles with different divergence length and divergence angle were numerically investigated. One main conclusion is that formation of normal shock wave inside the nozzle reduces the thrust produced by the nozzle. The thrust reduction observed is as high as $36 \%$.

Results also reveal that reducing the nozzle's divergence angle from $28^{\circ}$ to $24^{\circ}$ while maintaining the area ratio decreasesthe thrust produced by approximately $18 \%$. In contrast, reducing the nozzle's divergence angle from $18^{\circ}$ to $16^{\circ}$ while maintaining the area ratio causes unnoticeable gain in thrust, which is less than $3 \%$.

An analysis of flow characteristic inside all nozzles leads to a conclusion that separation of flow from nozzle wall cannot be eliminated by reducing the divergence angle while maintaining the area ratio. In addition, an increase in viscous loss reduces the strength of normal shock inside the nozzle.

\section{ACKNOWLEDGEMENT}

The authors would like to acknowledge and thank the Almighty God, all colleagues that contributed either direct or indirectly to this research, to Faculty of Mechanical Engineering, University Technology of MARA and all the members in this project especially Mr. Ahmad Hussien Abdul Hamid. 


\section{REFERENCES}

[1] D. G. Shepherd, Aerospace propulsion (American Elsevier Publishing Company, Inc., 1972).

[2] J. B. Pearson, D. B. Landrum, and C. W. Hawk, "Parametric Study of Solar Thermal Rocket Nozzle Performance," NASA Technical Memorandum 111354, (1994).

[3] S. P. Grisnik and T. A. Smith, "Experimental Study of Low Reynolds Number Nozzles," NASA Technical Memorandum 89858, (1987).

[4] A. D. Ketsdever, M. T. Clabough, S. F. Gimelshein, and A. Alexeenko, "Experimental and Numerical Determination of Micropropulsion Device Efficiencies at Low Reynolds Numbers," AIAA Journal (43), 1-10 (2005).

[5] M. V. Whalen, "Low Reynolds Number Nozzle Flow Study," NASA Technical Memorandum 100130, (1987).

[6] S. B. Verma, R. Stark, and O. Haidn, "Relation between shock unsteadiness and the origin of side-loads inside a thrust optimized parabolic rocket nozzle," Journal of Aerospace Science and Technology, 1-10 (2006).

[7] J. Östlund, "Flow processes in rocket engine nozzles with focus on flow separation and sideloads," Royal Institute of Technology Department of Mechanics S-100 44 Stockholm, Sweden, Tech. Rep. (2002).

[8] R. L. Bayt, "Analysis, Fabrication and Testing of a MEMS-based Micropropulsion System," Ph.D. thesis, Massachusetts Institute of Technology, (1999).

[9] A. Nebbache and C. Pilinski, "Pulsatory phenomenon in a thrust optimized contour nozzle," Journal of Aerospace Science and Technology,295-308 (2006).

[10] J. Östlund, "Supersonic flow separation with application to rocket engine nozzles," Royal Institute of Technology Department of Mechanics S-100 44 Stockholm, Sweden, Tech. Rep. (2004).

[11] M. Almqvist, "Semi-empirical model for supersonic flow separation in rocket nozzles," M.S. thesis, Lulea University of Technology, Sweden, (2005).

[12] A. Raheem and V. Babu, "Numerical Simulations of Unsteady Flows In Solid Rocket Motors," Proceedings of $10^{\text {th }}$ AIAA / CEAS Aero acoustics Conference, AIAA 2004-2878, 1-15 (2004).

[13] V. H. Rapp, J. Jacobsen, M. Lawson, A. Parker, and K. Chen, "Design, Construction and Testing of a Desktop Supersonic Wind Tunnel," American Journal of Undergraduate Research (4), 1-10 (2005).

[14] FLUENT Tutorial Guide, Modeling External Compressible Flow,Fluent Inc., (2003).

[15] FLUENT User's Guide, Modelling Turbulence, Fluent Inc., (2003).

[16] A. Charmeau and S. Anghaie, "A Hybrid Fine-Coarse Computational Mesh Simulation Tool for Space Nuclear Systems," in Proceedings of the Space Nuclear Conference, (2005). 